\title{
Seismic effect of Composite structural member in RC framed structure with shear wall
}

\author{
Prof A.Amarnath \\ Assistant Professor \\ Department of Civil Engineering \\ S.G.Balekundri Institute of Technology, Belagavi, Karnataka, India \\ Prof Sagar L Belgaonkar \\ Assistant Professor \\ Department of Civil Engineering \\ S.G.Balekundri Institute of Technology, Belagavi, Karnataka, India
}

RashmiT H

Undergraduate Student, Department of Civil Engineering, S.G.Balekundri Institute of Technology, Belagavi, Karnataka, India

Preeti Patil

Undergraduate Student, Department of Civil Engineering, S.G.Balekundri Institute of Technology, Belagavi, Karnataka, India

Shifa Mulla

Undergraduate Student, Department of Civil Engineering, S.G.Balekundri Institute of Technology, Belagavi, Karnataka, India

\author{
Amitkumar \\ Undergraduate Student, Department of Civil Engineering, \\ S.G.Balekundri Institute of Technology, Belagavi, Karnataka, India
}

\begin{abstract}
Shear wall is designed to resist lateral forces like Earthquake loads, wind loads...etc. Composite members are made up of two different materials example: steel and concrete. In this paper the effect of lateral forces on RCC structure without shear wall and with different locations of the shear wall in the building. In this paper we have analyzed that the RCC structure with slab as a composite member and shear wall. We are analyzing G+20 story RCC structure slab as composite member with different locations of the shear walls and results are compared for the various seismic parameters such as Base shear, Modal time period, Story displacement, Story Stiffness, Story drift of the structure for all structure. As the shear wall with composite slab structure is having more lateral stiffness, the displacement and modal time period shows the variation. The building is analyzed and design for seismic loading by using ETABS 2013 software.
\end{abstract}

Keywords - Composite member, RCC structure, Shear wall.

\section{INTRODUCTION}

For the design of structure as good lateral force resistant structure it is important to know about various types of loads and its effects on structure therefore it is essential to know about the lateral loads ex : earthquake load, wind load etc. Earthquake may be defined as a wave motion generated by the forces in constant movement under the surface layer of the earth. In some of the cases wind load effect is more than earthquake load it depends on the zone factor as per IS codes.

This section provides an introduction about shear walls and use of shear wall in a structure can resist earthquake and wind forces this can be done by comparing the various results. Shear walls are vertical elements of the horizontal 
force resisting system. Shear wall should be located on each level of the structure including the crawl space. Shear wall resist forces like shear forces and uplift forces. These shear wall provide the necessary strength and stiffness to resist horizontal earthquake forces.

Composite member can be defined as the member which is made up of two different types of materials example: steel and concrete. Composite member combines the better properties in both, concrete in compression and steel in tension; they have almost same thermal expansion and result in speedy construction.

Composite member which is used in paper is shown below:

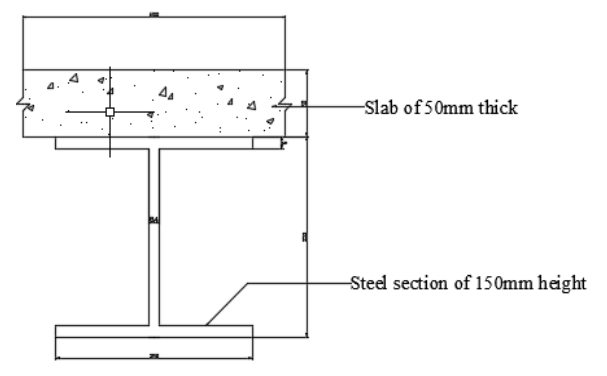

\section{Shear wall -}

Shear wall are the vertical elements of horizontal force resisting system. Building with shear wall and moment resisting system. This system consist of shear wall and moment resisting frame such that

The two systems are designed to resist the total design force in proportion to their lateral stiffness considering the interaction of building with moment resisting frame system and building with shear wall system at all floor levels.

The moment resisting frames are designed to independently resist at least $25 \%$ of the design seismic base shear. In general a dual system comparably has a higher value of $\mathrm{R}$ ( Response reduction factor ), since secondary lateral support system is available to assist the primary non-bearing lateral support system.

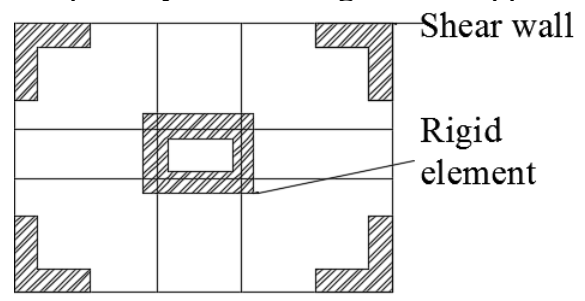

Figure 1. Building with Shear wall and moment resisting frame.

\section{II.METHODOLOGY}

\section{Structural Models Considered Using ETABS -}

In the present study, $\mathrm{G}+20$ stories with composite slab are considered for models. The various parameters are to be compared in the mentioned models such as story drift, displacement, natural period, story forces, stiffness.

Model 1 : RCC building structure with Shear wall along X direction.

Model 2 : RCC building structure with Shear wall along Y direction.

Model 3 : RCC building structure with Shear wall as Box.

Model 4 : RCC building structure with Shear wall at periphery.

Model 5 : RCC building structure with L shaped shear wall/ Shear wall at corner.

Model 6 : RCC building structure without shear wall.

The building structure are modeled in ETABS software as a fixed base with mentioned models. Total height of the building is $63 \mathrm{~m}$, each story heights of $3 \mathrm{~m}$.

4. Physical Properties of Reinforced Concrete-

a) Weight per unit volume, $\mathrm{w}=24.5166 \mathrm{kN} / \mathrm{m}^{3}$

Modulus of elasticity, $\mathrm{E}=22360.68 \mathrm{~N} / \mathrm{mm}^{2}$

Co-efficient of Thermal expansion, $\mathrm{A}=0.0000055 /{ }^{\circ} \mathrm{c}$

Compressive strength of concrete $f_{c k}=20 \mathrm{~N} / \mathrm{mm}^{2}$
Mass per unit volume. $\mathrm{m}=2500 \mathrm{~kg} / \mathrm{m}^{3}$

Poisson's ratio, $\mathrm{U}=0.2$

Shear modulus, $\mathrm{G}=9316.95 \mathrm{~N} / \mathrm{mm}^{2}$ 
b) Size of Members

$$
\begin{array}{ll}
\text { Beam }=300 \mathrm{~mm}^{*} 450 \mathrm{~mm} & \text { Column }=300 \mathrm{~mm} * 450 \mathrm{~mm} \\
\text { Deck Slab thickness }=200 \mathrm{~mm} & \text { Shear wall thickness }=230 \mathrm{~mm}
\end{array}
$$

5. Live Load Considered (IS : 875 (part-II) 1987) $=3 \mathrm{kN} / \mathrm{m}^{2}$

6. Seismic Load Considered (IS 1893 (part I):2002)

\section{Seismic co-efficient:}

Seismic zone =III.

Importance factor, $\mathrm{I}=1.5$

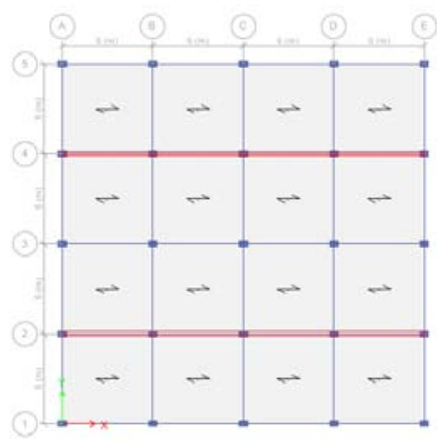

Fig.1 Plan for model 1

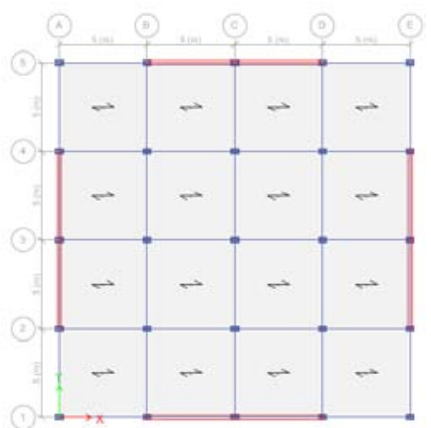

Fig.4 Plan for model 4

Type of soil = Type II(Medium soil).

Response reduction factor, $\mathrm{R}=5$

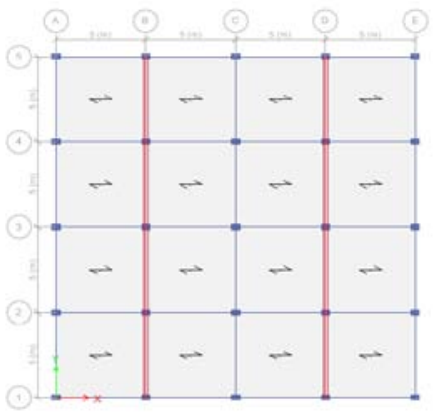

Fig.2 Plan for model 2

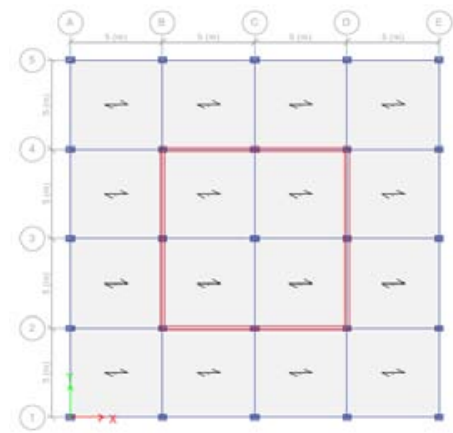

Fig.3 Plan for model 3

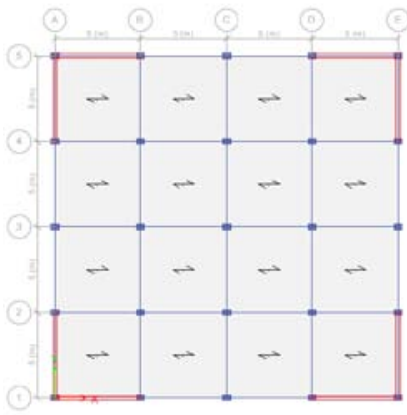

Fig.5 Plan for model 5

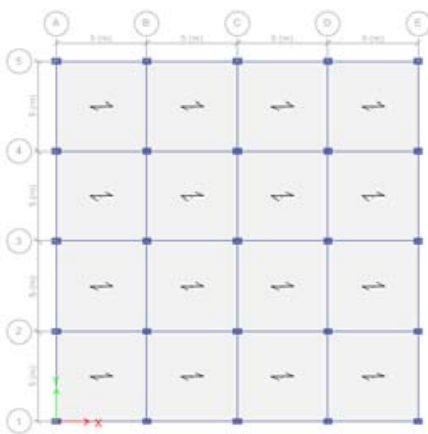

Fig.6 Plan for model 6

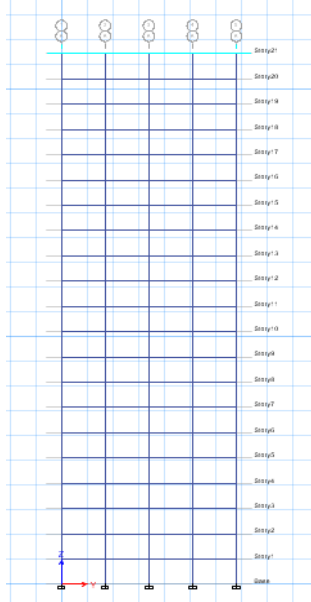


Fig.7 Elevation for RCC building structure without shear wall.

\section{III.RESULT AND DISCUSSION}

Table no.1 Natural period for all Models

\begin{tabular}{|c|c|c|c|c|c|}
\hline \multicolumn{5}{|c|}{ Natural Period (Sec) } \\
\hline Model 1 & Model 2 & Model 3 & Model 4 & Model 5 & Model 6 \\
\hline 5.960 & 5.054 & 1.451 & 2.159 & 2.570 & 5.602 \\
\hline
\end{tabular}

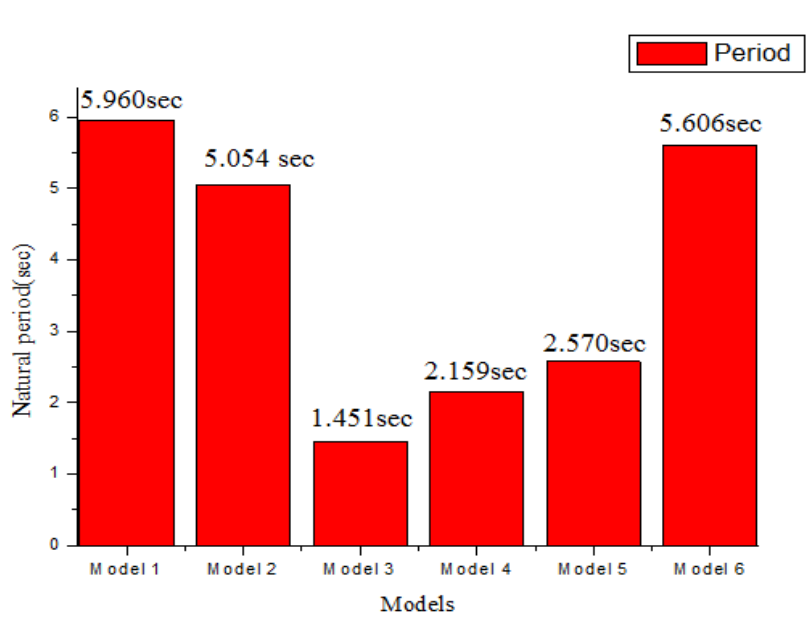

Graph 1 Natural period graph for all Models(Table no.1)

a. Natural Period:

1. From Graph 1 the natural period of model 1 is 5.960 sec and model 3 is 1.451 sec. From this, the model 3 natural period is $76 \%$ lesser than that of model 1.

2. From Graph 1, as comparing to the natural period for model 1, model 2 and model 6 it can be observed that the variation in the natural period is not more than $15.20 \%$.

3. Similarly comparing to the natural period for model 3, model 4 and model 5 it can be observed that the variation in the natural period is not more than $44 \%$.

4. From Graph 1 we can observe that the natural period of model 3 is least, as it has box shaped shear wall.

Table no. 2 Displacement for all Models in mm

\begin{tabular}{|c|c|c|c|c|c|c|}
\hline \multicolumn{9}{|c|}{ Displacement for all Models(mm) } \\
\hline Story & Model 1 & Model 2 & Model 3 & Model 4 & Model 5 & Model 6 \\
\hline 21 & 20.80 & 99.50 & 28.50 & 41.50 & 48.00 & 88.80 \\
\hline 20 & 19.50 & 97.80 & 26.90 & 39.10 & 45.30 & 87.20 \\
\hline 19 & 18.30 & 95.50 & 25.10 & 36.60 & 42.50 & 85.10 \\
\hline 18 & 17.00 & 92.70 & 23.40 & 34.20 & 39.70 & 82.40 \\
\hline 17 & 15.70 & 89.30 & 21.70 & 31.70 & 36.70 & 79.40 \\
\hline 16 & 14.40 & 85.40 & 19.90 & 29.20 & 34.10 & 75.90 \\
\hline 15 & 13.10 & 81.10 & 18.20 & 26.70 & 31.20 & 72.00 \\
\hline 14 & 11.90 & 76.40 & 16.40 & 24.20 & 28.30 & 67.80 \\
\hline 13 & 10.60 & 71.50 & 14.70 & 21.70 & 25.50 & 63.40 \\
\hline 12 & 9.40 & 66.20 & 13.10 & 19.20 & 22.60 & 58.80 \\
\hline 11 & 8.20 & 60.80 & 11.40 & 16.80 & 19.80 & 53.90 \\
\hline 10 & 7.00 & 55.20 & 9.80 & 14.40 & 17.10 & 48.90 \\
\hline
\end{tabular}


International Journal of Innovations in Engineering and Technology (IJIET)

http://dx.doi.org/10.21172/ijiet.82.001

\begin{tabular}{|c|c|c|c|c|c|c|}
\hline 9 & 5.90 & 49.50 & 8.30 & 12.20 & 14.40 & 43.80 \\
\hline 8 & 4.90 & 43.60 & 6.90 & 10.00 & 11.90 & 38.60 \\
\hline 7 & 3.90 & 37.80 & 5.50 & 8.00 & 9.50 & 33.40 \\
\hline 6 & 3.10 & 31.90 & 4.30 & 6.20 & 7.30 & 28.20 \\
\hline 5 & 2.30 & 26.00 & 3.20 & 4.50 & 5.30 & 23.00 \\
\hline 4 & 1.60 & 20.20 & 2.20 & 3.00 & 3.60 & 17.90 \\
\hline 3 & 1.00 & 14.40 & 1.40 & 1.80 & 2.20 & 12.80 \\
\hline 2 & 0.50 & 8.70 & 0.70 & 0.90 & 1.10 & 7.80 \\
\hline 1 & 0.20 & 3.40 & 0.30 & 0.30 & 0.30 & 3.00 \\
\hline Base & 0.00 & 0.00 & 0.00 & 0.00 & 0.00 & 0.00 \\
\hline
\end{tabular}

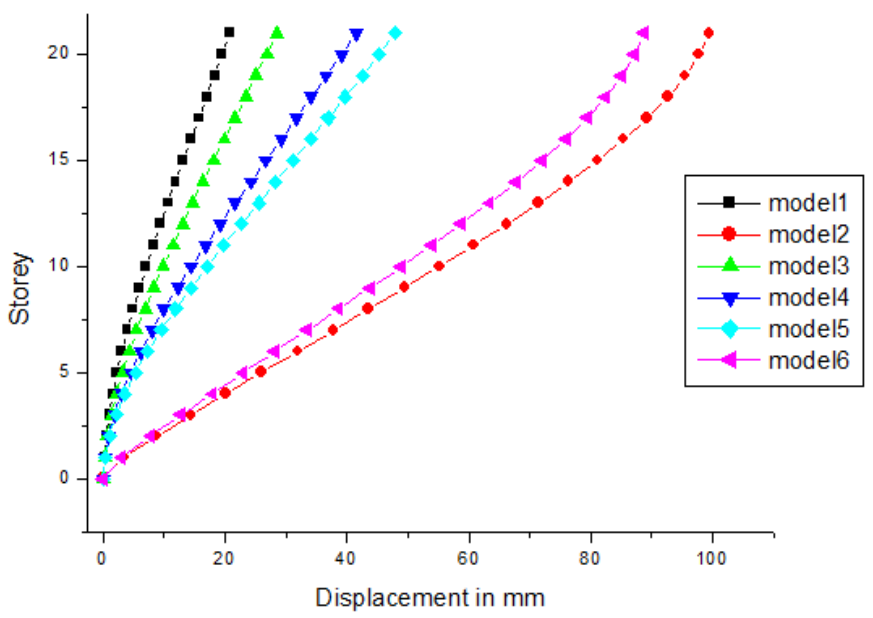

Graph 2.Displacement for all Models

b. Displacement :

1 From Graph 2, comparing the Displacements of model 1 and model 2, the Displacement of model 2 is $79 \%$ greater than that of model 1.

2 From Graph 2, comparing the Displacements of model 6 and model 2, the Displacement of model 2 is $10.75 \%$ higher than that of model 6.

3 Similarly comparing the Displacements of model 1 and model 3, the Displacement of model 3 is $27 \%$ greater than that of model 1 .

4 From Graph 2, it can be observed that model 1 has less Displacement as compared to other models.

Table no.3 Stiffness for all Models in $\mathrm{kN} / \mathrm{m}$

\begin{tabular}{|c|c|c|c|c|c|c|}
\hline \multicolumn{7}{|c|}{ Stiffness for all Models in $\mathrm{kN} / \mathrm{m}$} \\
\hline Story & Model 1 & Model 2 & Model 3 & Model 4 & Model 5 & Model 6 \\
\hline 21 & 355304.52 & 68954.09 & 190937.82 & 91279.57 & 69781.56 & 67831.67 \\
\hline 20 & 699474.00 & 101244.10 & 374595.92 & 179515.63 & 137096.20 & 98087.22 \\
\hline 19 & 1004963.87 & 116348.95 & 537240.53 & 257601.42 & 196153.36 & 113090.35 \\
\hline 18 & 1277646.46 & 125313.73 & 681473.09 & 326223.92 & 247508.93 & 122227.55 \\
\hline 17 & 1523571.91 & 131273.87 & 810734.00 & 386853.63 & 292293.24 & 128412.37 \\
\hline 16 & 1748660.80 & 135568.67 & 928234.09 & 440996.08 & 331723.34 & 132925.18 \\
\hline 15 & 1958722.27 & 138854.84 & 1037142.01 & 490228.11 & 367064.55 & 136413.00 \\
\hline 14 & 2159561.72 & 141504.11 & 1140592.64 & 536145.93 & 399583.77 & 139247.39 \\
\hline 13 & 2357184.29 & 143744.80 & 1241794.85 & 580387.68 & 430556.36 & 141659.42 \\
\hline 12 & 2558106.06 & 145727.95 & 1344188.58 & 624695.34 & 461309.00 & 143803.28 \\
\hline
\end{tabular}


International Journal of Innovations in Engineering and Technology (IJIET)

http://dx.doi.org/10.21172/ijiet.82.001

\begin{tabular}{|l|l|l|l|l|l|l|}
\hline 11 & 2769818.43 & 147560.17 & 1451682.34 & 671027.55 & 493301.02 & 145788.61 \\
\hline 10 & 3001498.24 & 149321.60 & 1569014.98 & 721743.90 & 528257.98 & 147698.29 \\
\hline 9 & 3265145.09 & 151076.35 & 1702332.43 & 779909.94 & 568391.23 & 149598.93 \\
\hline 8 & 3577507.92 & 152878.99 & 1860160.93 & 849827.21 & 616777.99 & 151547.39 \\
\hline 7 & 3963568.52 & 154778.87 & 2055161.15 & 938019.94 & 678068.30 & 153595.24 \\
\hline 6 & 4463339.02 & 156824.11 & 2307542.40 & 1055232.35 & 759921.29 & 155792.78 \\
\hline 5 & 5146477.06 & 158073.67 & 2652389.15 & 1220924.45 & 876262.60 & 158201.17 \\
\hline 4 & 6147640.77 & 161666.03 & 3157346.02 & 1474879.57 & 1055819.71 & 160960.66 \\
\hline 3 & 7771369.89 & 165391.49 & 3975157.54 & 1914207.73 & 1369917.20 & 164860.33 \\
\hline 2 & 10861798.00 & 176130.79 & 5527435.58 & 2851517.29 & 2058367.51 & 175766.62 \\
\hline 1 & 19776571.00 & 274888.92 & 10028048.00 & 6330166.04 & 4857058.19 & 274591.53 \\
\hline
\end{tabular}

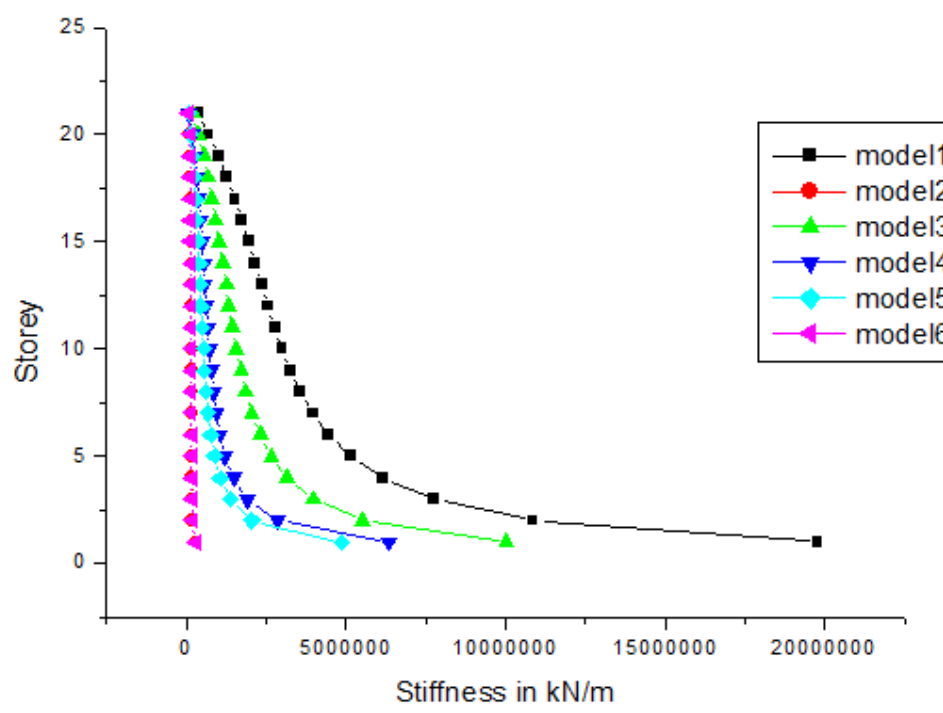

Graph.3. Stiffness for all Models

c. Stiffness:

1. From Graph 3, comparing the Stiffness of model 1 and model 6, the Stiffness of model 1 is $81 \%$ greater than that of model 6.

2. From Graph 3, comparing the Stiffness of model 1 and model 3, the Stiffness of model 1 is $46 \%$ greater than that of model 3.

3. Similarly comparing the Stiffness of model 4 and model 5, the Stiffness of model 4 is $24 \%$ greater than that of model 5.

4. From Graph 3 it can be observed that Stiffness of model 1 is maximum.

d. Story force:

1 Comparing the Story force of model 1 and model 6, the Story force of model 1 is $76 \%$ greater than that of model 6.

e. Drift:

1. Comparing the Drift of the model 2 and model 6, the Drift of the model 2 is $6 \%$ higher than that of model 6.

2. Similarly, comparing the Drift of the model 1, model 3, model 4 and model 5, the Drift of the model 5 is $53.76 \%$ higher than that of model 1.

\section{IV.CONCLUSION}


1. The Displacement of model 2 is $79 \%$ higher than that of model 1 . This is due to, in model 1 the shear wall is placed in $\mathrm{X}$ direction which resist the earthquake forces (as acting in In Plane direction).

2. The Displacement of model 3 is $27 \%$ higher than that of model 1 . This is due to, in model 3 the shear wall is placed in a box like structure, it acts as a single unit and resists most of the lateral forces. Thus the displacement of model 1 is less.

3. Model 1 has the least Displacement when compared to other models , as the earthquake forces are resisted in Inplane direction.

4. Stiffness of model 1 is $81 \%$ higher than that of model 6 , as the displacement for model 1is less Stiffness is more. i.e. $\mathrm{K}=\mathrm{F} / \Delta$.

5. Stiffness of model 1 is $46 \%$ higher than that of model 3 . This is due to, in model 1 shear wall present in $\mathrm{X}$ direction.

6. Model 1 has the least displacement when compared to other models. As the stiffness for the model 1 is more.

7. Story force for model 6 is least of all the models, because it is a structure without shear wall. Hence if the shear walls present in the structure, it acts as good earthquake resistant structure.

8. Drift of model 1 is least, as the displacement for model 1 is less and drift is directly proportional to displacement and it is resisting in plane direction.

\section{REFERENCES}

[1] Abhishek Sanjay Mahajan, Lakshman G, Kalurkar,"Performance analysis of RCC and Steel Concrete Composite Structure Under Seismic Effect”, International Research in engineering and technology, April 2017.

[2] K.G.Patwari, L.G.Kalurkar,”Comparative Study Of RC Flat Slab and Shear wall with Conventional Framed Structure in High rise Building”,International Journal of Engineering Research,27-28 Feb 2016.

[3] Karthik S, Uday kumar S, Geeta G,” Lateral Resistance Behaviour Of High Rise Building With Shear wall and Bracing System”,The International Journal of Science and Technology,Feb 2016.

[4] Khushbu Jani, Paresh V. patel,” Analysis and Design of Diagrid system for High Rise steel Building”,Procedia Engineering 51, 25 ${ }^{\text {th }}$ April 2013.

[5] Harikrushna kapadia, Gunvant solanki, Hitesh dhamliya,"Comparision Between RCC and Composite Structure Of Industrial Building”,International Journal of Advance Engineering and Research Development, December 2015.

[6] Shaikh Muffassir, L.G.Kalurkar,’Study of Wind Analysis of Multi-Storey Composite Structure For Plan Irregularity”, International Jouranal of Advanced Technology in Engineering and Science, September 2016.

[7] S.K.Duggal,” Earthquake Resistant Design Of Structure”,Oxford University Press, Second edition published in 2013.

[8] Pankaj Agarwal, Manish Shrikhande,”Earthquake Resistant Design Of Structures”,PHI Learning Private Limited, Delhi.2014.

[9] “IS 1893(part 1): 2002” Criteria for Earthquake Resistant Design Of Structure Part 1 General Provisions and Buildings(Fifth Revision) Bureau Of Indian Standards New Delhi.

[10] “IS 456: 2000”Plain And Reinforced Concrete Code Of Practice(Fourth Revision) Bureau Of Indian Standards New Delhi. 